Sains Malaysiana 50(5)(2021): 1415-1424

http://doi.org/10.17576/jsm-2021-5005-20

\title{
Potensi Pembangunan Kajian Autofagi dalam Fungsi Endotelium Otak Manusia
} (Development Potential of Autophagy Studies in the Human Brain Endothelium Functions)

\author{
Nurul Farhana Jufri*, Siti Nurdiyana Mohd Saleh, Nor Atikah Safirah Juhari, Farah Wahida \\ IBRAHIM \& ASMAH HAMID
}

\begin{abstract}
ABSTRAK
Autofagi adalah proses fisiologi yang terlibat dalam penggantian komponen sel dan berfungsi sebagai mekanisme kelangsungan hidup sementara semasa kebuluran sel akibat kekurangan sumber makanan. Proses ini melibatkan tapak jalan lisosom yang menguraikan bahan yang terdapat dalam sitoplasma seperti organel dan makromolekul. Keberlangsungan proses autofagi bergantung kepada fungsi normal lisosom untuk mengurai dan mengitar semula bahan yang terkumpul di dalam autofagosom. Kegagalan fungsi pada lisosom akan mempengaruhi fungsi autofagi. Secara in vitro, proses autofagi boleh direncat dengan menggunakan bahan kimia seperti amonium klorida yang akan mengganggu fungsi lisosom melalui peningkatan pH lisosom yang seterusnya menghalang keberkesanan enzim lisosom. Hal ini akan menyebabkan kandungan di dalam autofagosom tidak dapat diurai dan meningkatkan penimbunan autofagosom yang mengandungi protein yang rosak. Penimbunan protein yang rosak ini telah dikenal pasti sebagai salah satu patogenesis penyakit neurodegenerasi yang kini dikaitkan dengan ketidakfungsian sel endotelium di otak. Perencatan tapak jalan autofagi-lisosom ini akan menyebabkan gangguan pembentukan struktur autofagi dan lisosom yang seterusnya menyebabkan peningkatan atau penurunan ekspresi protein seperti LC3 dan p62 yang terlibat dalam tapak jalan ini. ICAM-1, eNOS dan Claudin-5 pada sel endotelium merupakan antara penanda yang berpotensi digunakan dalam pengenalpastian ketidakfungsian yang mungkin berlaku pada sel endotelium otak manusia.
\end{abstract}

Kata kunci: Autofagososm; disfungsi sel endotelium; ketidakfungsian; lisosom; sel endotelium

\section{ABSTRACT}

Autophagy is a physiological process involved in replacing cellular components and function as a temporary survival mechanism during cell starvation. This process involves lysosomal pathway that degrades materials contained in the cytoplasm such as organelles and macromolecules. The occurrence of the autophagy process depends on normal lysosomal function which degrades and recycles accumulated cellular material in autophagosome. Lysosome dysfunction will eventually affects autophagy function. In in vitro, autophagy can be inhibited by using chemical such as ammonium chloride which will disturb lysosome function by increasing lysosome's $p H$ hence hindering the effectiveness of lysosomal enzymes. This prevents autophagosomal content degradation, thus, leading to the accumulation of autophagosomes containing defective proteins. Accumulation of the defective proteins has been identified as one of the pathogenesis in neurodegenerative diseases which now is linked with endothelial dysfunction. Inhibition of this autophagy-lysosome pathway results in disruption of the formation of autophagy and lysosome structures that leads to the increase or decrease in protein expressions involved in this pathway such as LC3 and p62. Other markers such as ICAM-1, eNOS, and Claudin-5 in endothelial cell are among potential markers to be used in identification of dysfunction that may happen in context of human brain endothelial cell.

Keywords: Autophagosome; endothelial cell; endothelial dysfunction; lysosome

\section{PENGENALAN}

Autofagi berasal daripada perkataan Yunani yang terdiri daripada perkataan 'auto' bermaksud sendiri dan 'fagi' yang bermaksud makan (Yang \& Klionsky 2010).
Sehubungan dengan itu, autofagi didefinisikan sebagai proses memakan diri sendiri atau secara saintifiknya suatu mekanisme penguraian dan kitar semula organel sel atau protein (Chun \& Kim 2018). Autofagi bertindak sebagai 
agen pembersihan yang akan mengumpulkan organel yang telah rosak, penggumpalan protein serta makromolekul lain ke dalam satu vesikel untuk ditindakkan oleh lisosom. Autofagi merupakan salah satu proses biologi yang penting dalam badan manusia dalam mengawal atur homeostasis sel. Proses ini terlibat dalam menjana tenaga semasa kekurangan bekalan nutrisi atau kebuluran melalui proses penguraian dan kitar semula makromolekul. Selain itu, proses ini juga terlibat dalam mekanisme pertahanan semasa stres (Jiang et al. 2016). Ketidakfungsian proses autofagi boleh menyebabkan penimbunan protein yang rosak dan penggumpalan protein yang tidak normal yang seterusnya membawa kepada kerosakan sel dan melibatkan perubahan ketelapan membran serta perubahan morfologi (Chun \& Kim 2018).

Ketidakfungsian autofagi boleh disebabkan oleh pelbagai faktor seperti penuaan dan kegagalan fungsi lisosom. Ia boleh berlaku pada pelbagai sel dalam tubuh manusia seperti sel ginjal, hati, jantung dan otot. Kini, fokus terhadap kegagalan proses ini dalam sel endotelium otak manusia semakin menjadi tumpuan memandangkan sel ini merupakan salah satu komponen dalam struktur rintangan darah otak. Struktur ini berfungsi dalam mengawal pertukaran molekul antara aliran darah dan parenkima otak bagi mengekalkan homeostasis sistem saraf pusat. Gangguan atau kecacatan pada fungsi dan struktur rintangan darah otak telah dikaitkan dengan patogenesis penyakit neurovaskular seperti Alzheimer.

\section{MEKANISME TINDAKAN DAN PERANAN AUTOFAGI}

Proses autofagi boleh dibahagikan kepada 3 jenis iaitu makroautofagi, mikroautofagi dan pengiring-perantaraan autofagi. Makroautofagi akan mengumpulkan organel yang telah rosak ke dalam vakuol autofagi dan bergabung dengan lisosom bagi proses peguraian. Manakala mikroautofagi melibatkan pembentukan membran lisosom yang akan mengelilingi dan mengumpulkan organel untuk proses degradasi (Tekirdag \& Cuervo 2018). Sementara itu, proses pengiring-perantaraan autofagi melibatkan pembentukan asid amino khusus untuk dikesan oleh pengiring Hsc70 seterusnya dihantar ke lisosom melalui interaksi dengan reseptor Lamp2a (Bonaldo \& Sandri 2013).

Proses autofagi merupakan proses kompleks yang melibatkan proses pembentukan vesikel yang akan memanjang dan molekul sasaran seperti gumpalan protein dan organel yang telah tua dan dikumpulkan ke dalam vesikel yang dikenali sebagai autofagosom. Vesikel ini terdiri daripada dua lapisan membran yang akan bergabung dengan lisosom bagi membentuk autolisosom. Lisosom mengandungi enzim hidrolase bagi menguraikan kandungan autolisosom. Hasil proses ini akan menghasilkan komponen sel yang baru atau penjanaan tenaga (Cuomo et al. 2019). Pembentukan ini dirangsang oleh faktor persekitaran seperti tekanan sel, kebuluran atau kehadiran patogen (Mizushima et al. 2008). Apabila dirangsang, protein kinase adenosin-monofosfat (AMPK) akan teraktif, terfosforilasi dan mengaktifkan ULK-1. Pengaktifan ULK-1 menghasilkan kompleks Atg14LBeclin 1-Vps (vacuolar protein sorting), 34-Vps15 yang akan menukarkan fosfatidilinositol (PI) kepada fosfatidilinositol-3-fosfat (PI3P) yang akan menyebabkan pengumpulan protein Atg lain dan pemanjangan fagofor (Rajah 1) (Chun \& Kim 2018).

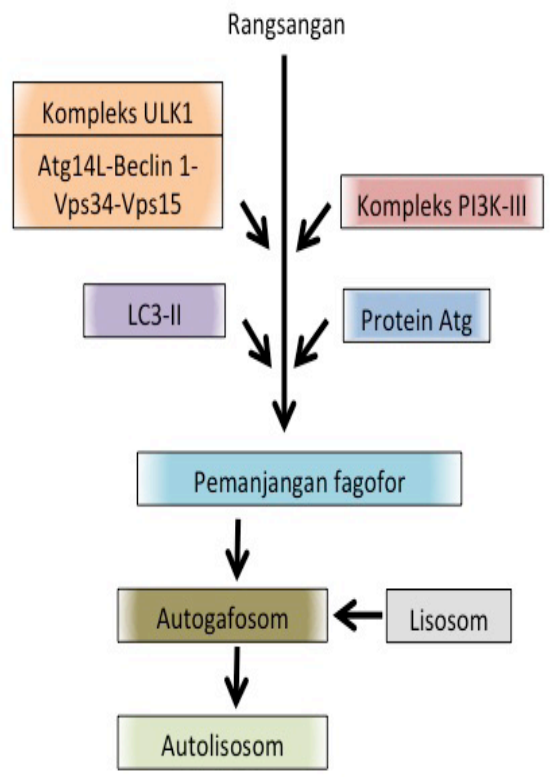

RAJAH 1. Ringkasan proses pembentukan autolisosom 
Apabila proses autofagi diaktifkan, protein mikrotubul-terkait rantaian ringan 3 (light chain3) (LC3) dalam sitosol akan berubah kepada LC3-1 sebelum menjadi LC3-II. LC3-II akan menjadi reseptor pada struktur fagofor dan berinteraksi dengan molekul pada sasaran autofagi seperti gumpalan protein dan organel yang rosak. Selain itu, protein p62 akan hadir pada autofagosom dan mengikat pada struktur LC3 bagi menggalakkan proses penguraian (Bhutia et al. 2013).

Autofagosom kemudiannya akan bergabung dengan lisosom yang mengandungi enzim degradasi hidrolase bagi membentuk autolisosom. Kandungan dalam autolisosom akan mengalami penguraian dan pemprosesan pembentukan molekul baru. Asid lemak dan asid amino akan dibawa kembali kepada sitosol dengan menggunakan pengangkut lisosom. Proses ini memainkan peranan penting dalam kemandirian hidup sel (Bhutia et al. 2013).

\section{PERANAN LISOSOM DALAM PROSES AUTOFAGI}

Lisosom merupakan organel yang hadir dalam hampir semua sel eukariot serta kaya dengan enzim hidrolitik. Dalam sel mamalia, saiz lisosom adalah antara 0.1 hingga $1.0 \mathrm{~mm}$, yang dianggap lebih kecil daripada saiz autofagosom yang secara purata antara 0.5 hingga 1.5 mm (Shen \& Mizushima 2014). Secara umumnya, lisosom berperanan dalam proses penguraian makromolekul yang dihasilkan daripada ruang ekstrasel menerusi endositosis atau fagositosis dan komponen intrasel seperti protein dan organel daripada sitoplasma menerusi proses autofagi (Eskelinen 2006; Kaushik \& Cuervo 2012).

Salah satu ciri biokimia lisosom yang paling utama ialah mempunyai lumen berasid iaitu antara $\mathrm{pH} 4.5$ hingga 5.0 yang menyediakan keadaan optimum untuk enzim hidrolisis melaksanakan fungsi sebagai pemangkin. Selain itu, lumen lisosom juga mengandungi lebih daripada 50 bahan termasuklah enzim protease, peptidase, fosfatase, nuklease, glikosidase, sulfatase dan lipase. Pengasidan lisosom dikekalkan oleh membran lisosom yang mengandungi lebih daripada 20 protein membran seperti protein membran berkait lisosom (lysosomeassociated membrane protein, LAMP) 1 dan 2 (Shen \& Mizushima 2014).

Semasa penemuan lisosom pada tahun 1956, kumpulan penyelidik Christian DeDuve telah menerangkan satu proses pencernaan atau penguraian komponen sitoplasma di dalam lisosom, yang kemudiannya telah dikenal pasti sebagai proses autofagi (Eskelinen \& Saftig 2009; Nixon 2013). Selain itu, kebanyakan sel boleh menjalankan proses autofagi menerusi mekanisme berbeza bergantung kepada cara produk yang akan diurai (atau dikenali sebagai kargo) yang dihantar ke lisosom (Kaushik \& Cuervo 2012). Hal ini menunjukkan bahawa lisosom memainkan peranan yang penting di dalam proses autofagi memandangkan proses autofagi yang lengkap memerlukan pencernaan autofagi oleh lisosom dan pembebasan metabolit untuk kegunaan semula dan fungsi isyarat.

\section{PENYAKIT BERKAITAN KETIDAKFUNGSIAN AUTOFAGI}

Autofagi adalah penting untuk homeostasis neuron dan ketidakfungsian autofagi secara langsung dikaitkan dengan peningkatan dalam penyakit kemerosotan neuron. Penyakit kemerosotan neuron adalah merupakan penyakit keturunan atau sporadik yang bergantung kepada umur dan ditunjukkan oleh kehilangan fungsi neuron secara progresif. Ciri-ciri umum dalam perkembangan penyakit adalah ketidakfungsian mitokondria dan pengumpulan agregat protein akibat mutasi dan mekanisme penghapusan atau penguraian yang terjejas (Choi et al. 2013).

Pengumpulan agregat intrasel merupakan punca utama bagi penyakit kemerosotan neuron seperti penyakit demensia, Alzheimer, Huntington, Parkinson dan Creutzfeldt-Jakob. Sebagai contoh, pembentukan poliglutamina yang berulang seperti Huntington mutan (penyakit Huntington), bentuk mutan sinuklein alfa (penyakit Parkinson) dan bentuk tau (penyakit Alzheimer) yang berlainan bergantung kepada fungsi autofagi dalam menghapuskan atau menyingkirkan protein agregat ini daripada neuron. Kajian lepas juga telah membuktikan bahawa penyahaktifan gen yang terlibat dalam mengekodkan protein penting berkaitan autofagi seperti ATG5 dan ATG7 pada neuron telah menghasilkan pengumpulan agregat intrasel dan kemerosostan neuron dalam tikus kajian (Glick et al. 2010).

Autofagi juga terlibat sebagai mekanisme perlindungan dalam pelbagai penyakit kemerosotan neuron seperti penyakit Parkinson, Alzheimer dan Huntington kerana proses ini dapat menyingkirkan protein yang rosak (Chun \& Kim 2018). Berdasarkan kajian yang lepas, terdapat pengumpulan bukti yang menyatakan bahawa ketidakfungsian autofagi atau lisosom adalah merupakan salah satu mekanisme utama penyakit kemerosotan neuron seperti penyakit Alzheimer, Parkinson dan Huntington (Settembre et al. 2013). Ketidakfungsian autofagi di dalam neuron akan menghasilkan pengumpulan sekunder substrat toksik, protein beragregat dan organel yang rosak. Penyimpanan dan pengumpulan bahan ini akan mencetuskan proses penguraian neuron kerana ia adalah penentu kritikal kematian sel dalam sel selepas mitosis. 
Dalam penyakit kemerosotan neuron, proses autofagi terjejas dan terganggu. Berdasarkan kajian lepas, terdapat peningkatan pengumpulan autofagosom pada otak pesakit yang menghidap penyakit Alzheimer. Dalam kajian yang menggunakan model tikus pula, pengurangan protein autofagi telah menggalakkan kemerosotan neuron bergantung kepada umur dengan pengumpulan protein agregat (Choi et al. 2013).

Secara umum, proses penyakit kemerosotan neuron sering dikaitkan dengan keradangan kronik dan kesan anti-keradangan yang diperoleh daripada proses autofagi dipercayai boleh memberikan manfaat kepada kesihatan sistem neuron. Namun begitu, sekatan penghapusan atau penguraian protein agregat seperti amiloid beta, sinuklein alfa atau mitokondria yang rosak oleh autofagi mungkin menjadi faktor untuk penyakit kemerosotan neuron seperti penyakit Parkinson dan Alzheimer (Noratiqah et al. 2018).

\section{SEL ENDOTELIUM PADA OTAK MANUSIA}

Salur darah periferi terdiri daripada tiga lapisan iaitu tunika intima, tunika media dan tunika adventisia. Tunika intima membentuk lapisan yang paling dalam dan terdiri daripada sel endotelium. Lapisan ini akan bersentuhan secara langsung dengan aliran darah. Tunika media pula merupakan lapisan tengah yang terdiri daripada tisu otot licin dan elastin yang akan mengawal diameter salur darah. Sementara itu, lapisan yang paling luar adalah lapisan adventisia yang mengandungi kolagen dan fibroblas yang berfungsi memberikan sokongan pada struktur salur darah.
Sel endotelium merupakan sel skuamas ringkas yang membentuk dinding salur darah pada lapisan tunika intima ( $\mathrm{Si}$ et al. 2017). Sel ini berbentuk poligon dan berketebalan sebanyak 1-2 $\mu \mathrm{m}$ dan berdiameter 10-20 $\mu \mathrm{m}$. Sel endotelium merupakan lapisan yang paling dalam dan menyentuh secara langsung komponen darah menjadikannya mudah terdedah kepada komponen dalam darah.

Sel endotelium akan membentuk satu organ homeostatik yang amat penting dan merupakan asas untuk pengawalan kontraksi dan struktur vaskular. Sel endotelium juga memainkan peranan penting dalam fungsi fisiologi bagi mengawal vasomotor, peredaran darah, mengesan perbezaan rangsangan fizikal atau kimia yang berlaku dalam salur darah, proliferasi dan homeostasis (Rajendran et al. 2013).

Kapilari darah membentuk jaringan di keseluruhan tubuh. Namun struktur kapilari di otak adalah berbeza dengan struktur salur darah periferi. Perbezaan fenotip bergantung kepada lokasi serta struktur yang memberi ciri heterogen sel tersebut. Sel endotelium kapilari otak membentuk rintangan darah otak bagi mengawal kemasukan molekul ke dalam salur darah otak. Selain sel endotelium, sel perisit dan astrosit juga hadir di sekeliling jaringan kapilari otak (Rajah 2). Selain itu, sel endotelium pada otak juga tidak mempunyai bukaan liang fenestra sebaliknya struktur endotelium terdiri daripada protein yang membentuk persimpangan ketat melibatkan protein okludin, claudin dan molekul lekatan simpang bagi mengawal ketelapan membran (Komarova et al. 2017).

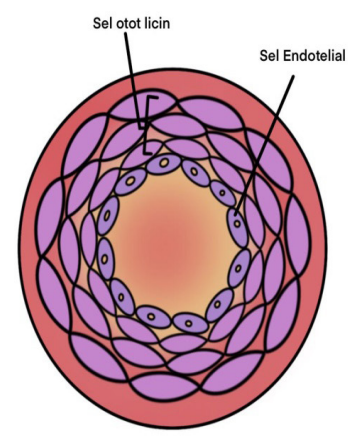

Struktur Asas Lapisan Salur Darah

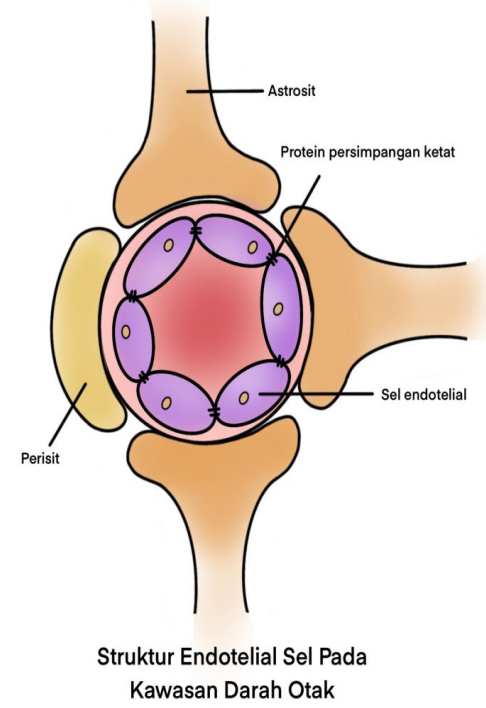

Kawasan Darah Otak

RAJAH 2. Struktur rintangan darah otak (kanan) yang mengandungi sel endotelial 
Rintangan darah otak wujud sebagai pengawal kemasukan dan pertukaran molekul yang selektif antara aliran darah dan parenkima seperti protein plasma dan leukosit. Rintangan darah otak hanya membenarkan kemasukan molekul tertentu seperti molekul hidrofobik bersaiz kecil (oksigen, karbon dioksida, hormon) sementara kemasukan molekul bersaiz besar dan molekul hidrofilik. Ini dicirikan dengan kehadiran protein persimpangan ketat dan kekurangan fenestra. Sel endotelium yang membentuk rintangan darah otak boleh dibezakan dengan sel endotelium periferi menerusi bilangan mitokondria yang banyak, pengurangan bilangan fenestra, aktiviti pinositosis yang minimum, dan kehadiran persimpangan ketat (Hawkins \& Davis 2005).

KETIDAKFUNGSIAN ENDOTELIUM PADA OTAK MANUSIA Ketidakfungsian sel endotelium secara umumnya ialah keadaan lapisan dalaman salur darah gagal untuk berfungsi disebabkan ketidakseimbangan penghasilan faktor pemvasodilatasi. Ia merupakan penunjuk awal atherosklerosis serta penyakit kardiovaskular. Pelbagai faktor dikaitkan menjurus kepada keadaan ini seperti tekanan oksidatif, darah tinggi, penuaan, tekanan hemodinamik serta penyakit metabolik (Gimbrone \& Garcia-Cardena 2016). Ketidakfungsian sel endotelium melibatkan perubahan ciri-ciri sel endotelium yang dicirikan dengan kegagalan vasodilatasi, keadaan proinflamasi, peningkatan ketelapan dan peningkatan ekspresi molekul pelekatan intraselular ICAM-1 (Nawawi et al. 2003). Selain itu, ia juga boleh ditakrifkan sebagai kekurangan kehadiran biokebolehdapatan nitrik oksida melalui penurunan sintesis atau penguraian nitrik oksida (Rajendran et al. 2013).

Apabila fungsi sel endotelium merosot, homeostasis vaskular terjejas dan membawa kepada pengurangan kesan anti-oksidan dan anti-radang, ketelapan vaskular meningkat dan peningkatan ekspresi sitokin serta molekul peradangan (Park \& Park 2015). Ketidakfungsian sel endotelium dicirikan oleh ketidakseimbangan pemvasodilatasi dan vasokonstriksi, peningkatan spesies oksigen reaktif, faktor pro-keradangan dan kekurangan nitrik oksida (Sun et al. 2020). Ketidakfungsian sel endotelium didapati menyumbang kepada permulaan serta perkembangan penyakit Alzheimer dan terdapat hipotesis mencadangkan hubungan antara perubahan serebrovaskular dan penyakit kemerosotan neuron (Di Marco et al. 2015).
Kajian lepas juga menunjukkan bahawa vaskulatur otak pada pesakit yang menghidap penyakit Alzheimer telah banyak dicirikan dengan ketidakfungsian sel endotelium dan didapati bahawa lebih banyak fungsi sistem rintangan darah otak terjejas berbanding dengan subjek kawalan yang telah dipadankan dengan usia (Zenaro et al. 2017). Selain itu, penurunan penanda sel endotelium CD34 dan CD31 telah diperhatikan di dalam otak pesakit yang menghidap penyakit Alzheimer. Hal ini menunjukkan bahawa terdapat degenerasi atau kemerosotan pada sel endotelium, perubahan unit neurovaskular dan peningkatan ketelapan rintangan darah otak semasa perkembangan penyakit ini (Magaki et al. 2018). Sel endotelium yang mengalami perubahan morfologi atau tercedera akan membebaskan faktor yang memudaratkan neuron pada otak pesakit yang menghidap penyakit Alzheimer (Grammas 2011).

\section{AUTOFAGI PADA SEL ENDOTELIUM OTAK MANUSIA}

Autofagi mempunyai pelbagai fungsi seperti mengurai protein dan organel yang terdapat dalam sitosol, menghapuskan protein yang tidak terbentuk dengan sempurna dalam keadaan tekanan yang tertentu serta mengawalatur homeostasis pada sel endotelium otak manusia yang mengelilingi kapilari darah yang membentuk rintangan darah otak (Yamazaki \& Kanekiyo 2017; Yoshii \& Mizushima 2017). Kekurangan nutrisi, tekanan retikulum endoplasma dan pengeluaran spesies oksigen reaktif yang berlebihan boleh mengaktifkan proses autofagi dalam sel endotelium (Xie et al. 2011).

Berdasarkan kajian lepas yang menjalankan perencatan genetik autofagi (Atg3) telah menghalang fosforilasi yang diaruh oleh nitrik oksida sintase endotelial (eNOS), penurunan generasi nitrik oksida, peningkatan pengeluaran spesies oksigen reaktif (ROS) dan penghasilan faktor pro-keradangan dan pelekatan. Hasil kajian ini menunjukkan kepentingan autofagi kepada fungsi sel endotelium yang normal (Bharath et al. 2017). Justeru, kehilangan atau ketidakfungsian autofagi akan membawa kepada pengumpulan metabolit atau substrat yang tidak didegradasi dalam sel-sel yang kemudiannya akan menyebabkan peningkatan spesies oksigen reaktif, molekul keradangan dan pelekatan serta ketelapan rintangan darah otak pada sel endotelium otak (Yamazaki \& Kanekiyo 2017). Pengumpulan yang berpanjangan daripada metabolit yang tidak diuraikan ini akan mengakibatkan kerosakan sel endotelium dan boleh mengakibatkan penyakit serebrovaskular atau penyakit kemerosotan neuron 
KESAN PERENCATAN PROSES AUTOFAGI DALAM SEL ENDOTELIUM

Kehilangan fungsi autofagi merupakan faktor risiko yang menyumbang kepada ketidakfungsian sel endotelium dan autofagi mungkin terlibat dalam pengawalan ketoksikan nitrik oksida. Apabila berlaku pengurangan atau penguraian nitrik oksida, kehilangan proses autofagi menggalakkan peningkatan spesies oksigen reaktif pada endotelium dan pengeluaran sitokin keradangan. Ini menunjukkan bahawa autofagi boleh mengawal homeostasis vaskular yang disebabkan oleh tekanan ricih melalui tapak jalan yang bergantung kepada eNOS. Gangguan proses autofagi dikaitkan dengan kedua-dua peningkatan dalam ROS dan peningkatan pengaktifan keradangan steril seperti yang dicirikan oleh pengaktifan inflamasom (Nussenzweig et al. 2015). Perencatan autofagi boleh mengakibatkan pengumpulan metabolit atau substrat yang tidak diuraikan. Ini akan menyebabkan peningkatan ROS, pengurangan nitrik oksida, peningkatan keradangan dan molekul lekatan serta peningkatan ketelapan rintangan darah otak (Yamazaki \& Kanekiyo 2017).

Di dalam otak manusia, kegagalan autofagi menyebabkan pengumpulan substrat toksik, protein agregat dan organel yang rosak. Pengumpulan bahan ini pada sel endotelium otak mencetuskan proses kemerosotan neuron kerana ia adalah penentu kritikal kematian sel selepas mitosis (Sambri \& Fraldi 2015). Apabila proses autofagi direncat di dalam sel endotelium, kecacatan glikolitik telah mengehadkan pengeluaran tenaga ATP sehingga tahap pengaktifan pengantaraan purinergik eNOS terkesan dan menyebabkan penghasilan nitrik oksida merosot di dalam sel endotelium (Bharath et al. 2017).

PERENCAT AUTOFAGI DALAM MODEL KAJIAN in vitro SEL

\section{ENDOTELIUM}

Proses autofagi boleh direncat secara farmakologi dengan mensasarkan PI3K kelas III yang terlibat dalam pembentukan autofagosom dengan menggunakan 3-metiladenin (3-MA). 3-MA merupakan perencat klasik autofagi yang juga merupakan perencat P13KP (Dai et al. 2016). Autofagi juga boleh direncat dengan mensasarkan penyatuan autofagosom dengan lisosom. Selain itu, perencatan boleh dilakukan dengan menggunakan perencat pam proton lisosom seperti bafilomisin A1. Bahan kimia seperti ammonium klorida juga boleh merencat proses autofagi menerusi perencatan penyatuan lisosom normal dengan autofagosom. Perubahan dalam aktiviti lisosom dan endosom/autofagosom boleh dilihat melibatkan peningkatan $\mathrm{pH}$ intravakuolar daripada keasidan normal (Ostrowski et al. 2016).

Selain itu, klorokuina merupakan sejenis ubat yang lebih dikenali sebagai ubat anti-malaria dan telah dikenal pasti boleh menjadi perencat pengasidan lisosom. Klorokuina juga telah digunakan sebagai bahan perencat dalam kajian berkaitan autofagi kerana ia boleh menghalang penyatuan autofagosom-lisosom dan aktiviti penguraian lisosom (Mauthe et al. 2018).

\section{PENANDA BIOLOGI BERKAITAN KETIDAKFUNGSIAN ENDOTELIUM DAN AUTOFAGI}

Untuk mengkaji hubungan antara ketidakfungsian autofagi dengan penyakit serebrovaskular, beberapa penanda berpotensi digunakan di dalam kajian. Penanda ketidakfungsian sel endotelium eNOS, penanda keradangan (ICAM-1), ekspresi penanda protein persimpangan ketat (Claudin-5), protein mikrotubulterkait rangkaian ringan 3 (LC3) dan protein p62 boleh dikesan dan diukur melalui pengurangan atau peningkatan ekspresi penanda tersebut (Rajah 3).

\section{PROTEIN LC3}

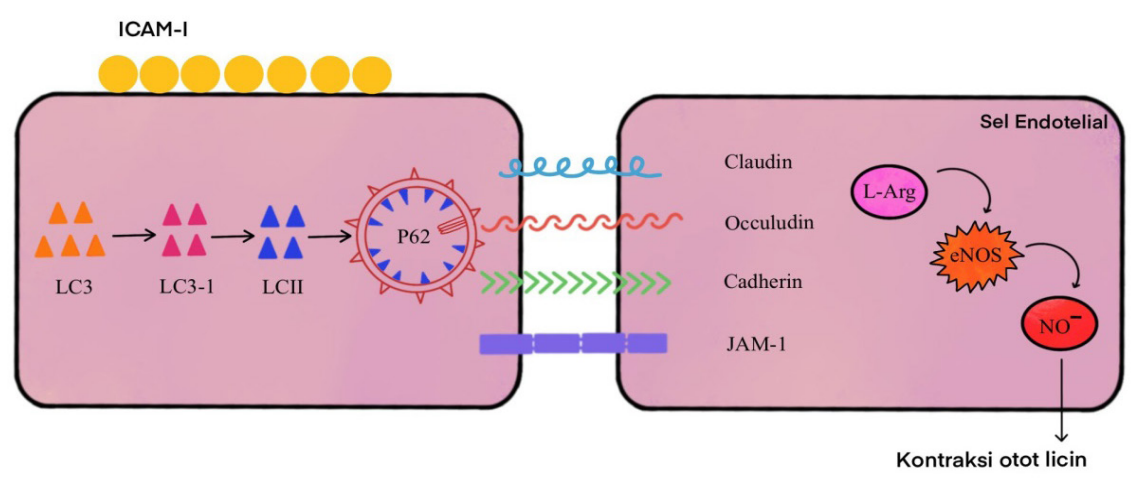

\section{Penanda Biologi Ketidakfungsian Proses Autofungsi Dalam Endotelium}


Protein mikrotubul-terkait rantaian ringan 3 (LC3) sering digunakan sebagai penanda biologi dalam kajian berkaitan autofagi. Apabila autofagi diaktifkan, prekursor LC3 akan disintesis. Atg4 kemudiannya akan memotong prekursor LC3 secara khusus pada asid amino 22 terminal C untuk menghasilkan LC3-I sitosol (Pugsley 2017). LC3-I sitosol seterusnya diproses menjadi membran-terikat LC3-II dengan bantuan beberapa protein Atg. LC3-II akan mengikat secara khusus pada membran fagofor bagi membantu proses pemanjangan membran fagofor dalam membentuk autofagosom (Green \& Levine 2014). Apabila autofagosom bergabung dengan lisosom menjadi autolisosom untuk proses penguraian, LC3-II akan turut diurai. Oleh yang demikian, sekiranya terdapat sebarang perencatan pada proses autofagi seperti ketidakfungsian lisosom akan menyebabkan peningkatan penanda protein LC3-II pada autofogosom.

\section{PROTEIN P62}

Protein p62 turut dikenali sebagai sequestosome 1 (SQSTM1) (Zhang et al. 2013). Protein p62 merupakan protein pelbagai fungsi yang mempunyai beberapa domain yang menjadikannya sebagai penyesuai autofagi. Antara domain yang terdapat pada protein p62 adalah C terminal ubiquitin-associated domain (UBA) dan LC3interacting region (LIR). Awalnya p62 akan berinteraksi dengan rangkaian ubiquitin melalui domain UBA. Seterusnya domain LIR akan berinteraksi dengan protein LC3 untuk membantu pembentukan dan penghantaran atau kematangan autofagosom (Liu et al. 2016). Kehadiran p62 akan menggalakkan proses penguraian protein dan akhir sekali protein p62 akan turut diuraikan oleh enzim hidrolase lisosom (Fang et al. 2017). Oleh itu, sekiranya berlaku ketidakfungsian autofagi pada sel, maka aras protein p62 akan meningkat berbanding sel normal kerana protein p62 tidak dapat diuraikan oleh lisosom (Pugsley 2017).

Kajian telah membuktikan bahawa kehadiran protein p62 pada inklusi protein merupakan fenomena normal yang sering dijumpai dalam penyakit kemerosotan neuron seperti penyakit Alzheimer dan Parkinson (Mizushima et al. 2010). Kajian yang dijalankan oleh Fang et al. (2015) menggunakan sel endotelium mikrovaskular otak manusia membuktikan bahawa perencatan autofagi melalui perencatan PI3K kelas III telah menyebabkan pengumpulan protein $\mathrm{p} 62$.

ENOS
Sel endotelium boleh menghasilkan dan merembeskan bahan anti-aterosklerosis seperti nitrik oksida (Ugusman et al. 2010). Nitrik oksida merupakan gas yang dihasilkan daripada metabolisme L-arginine oleh eNOS yang diekspresikan oleh sel endotelium dengan kehadiran kofaktor tetrahidrobiopterin (BH4) (Rajendran et al. 2013). eNOS bertanggungjawab dalam penghasilan dan pengeluaran nitrik oksida vaskular. Walau bagaimanapun, eNOS juga boleh menjadi penjana spesies oksigen reaktif dalam keadaan tertentu sebagai sebahagian daripada pengaktifan sel endotelium. Proses ini disebut sebagai penyahgandingan eNOS dan akan menghasilkan pembentukan superoksida jika kofaktor utama BH4 tidak hadir atau menjana hidrogen peroksida dalam kekurangan substrat L-arginin (Park \& Park 2015).

Ketidakfungsian sel endotelium juga ditakrifkan dengan kehadiran penurunan kadar biokebolehdapatan nitrik oksida (Rajendran et al. 2013). Hal ini kerana menerusi penurunan biokebolehdapatan nitrik oksida akan membentuk superoksida yang merupakan salah satu spesies oksigen reaktif yang akan mengganggu fungsi normal sel endotelium. Penurunan nitrik oksida menyebabkan kegagalan pengawalan pemvasokembangan vaskular, pelekatan leukosit dan agregasi platelet (Ugusman et al. 2014).

\section{ICAM-1}

Keradangan kronik telah dikaitkan dengan penyakit neuron yang berkait dengan penuaan termasuk penyakit Alzheimer serta penyakit yang berkaitan dengan ketidakfungsian sel endotelium (Grammas et al. 2011). Keradangan juga boleh mengurangkan biokebolehdapatan nitrik oksida yang akan menjejaskan fungsi normal sel endotelium menerusi peningkatan spesies oksigen reaktif. Apabila fungsi sel endotelium merosot, homeostasis vaskular akan terjejas dan membawa kepada pengurangan kesan anti-oksidan dan anti-radang, peningkatan kebolehtelapan vaskular kepada lipoprotein dan peningkatan ekspresi sitokin radang dan molekul pelekatan (Park \& Park 2015).

Ekspresi molekul pelekatan vaskular yang menjadi perantara bagi proses pengedaran leukosit adalah yang minimum atau tidak dapat dikesan di bawah keadaan fisiologi. Walau bagaimanapun, semasa keradangan otak berlaku, ekspresi molekul pelekatan sel endotelium meningkat dengan mendadak dan molekul pelekatan ini akan dibebaskan ke dalam peredaran darah. Hal ini boleh menjadikan molekul pelekatan sebagai penanda biologi bagi ketidakfungsian sel endotelium dan keradangan vaskular. Kajian lepas ada menunjukkan terdapat 
peningkatan aras molekul pelekatan yang larut seperti molekul pelekatan sel vaskular-1 (VCAM-1), ICAM-1, E-selectin dan P-selectin pada sampel plasma daripada pesakit berbanding subjek kawalan. Hal ini menunjukkan bahawa keradangan vaskular berlaku semasa penyakit Alzheimer (Zenaro et al. 2017).

Bagi penyakit Alzheimer, kajian lepas mendapati terdapat peningkatan yang ketara dalam perantara keradangan di dalam mikroedaran serebrum. Sel endotelium otak pada pesakit Alzheimer mengekspresikan tahap molekul pelekatan keradangan yang tinggi seperti ICAM-1 (Grammas 2011). Oleh yang demikian, penanda biologi bagi ketidakfungsian sel endotelium selalunya dalam bentuk larut ini boleh dikesan di dalam plasma pesakit (Rajendran et al. 2013).

Kajian sebelum ini telah menunjukkan bahawa terdapat tanda-tanda keradangan pada otak pesakit yang menghidap penyakit Alzheimer (Huang et al. 2015, Zenaro et al. 2017). Ketidakfungsian sel endotelium juga sering dipadankan atau dikaitkan dengan keradangan arteri. Oleh itu, ekspresi awal perantara keradangan pada otak pesakit yang menghidap penyakit seperti penyakit Alzheimer oleh sel bukan neuron seperti endotelium dapat dikesan bagi memantau perkembangan penyakit (Grammas et al. 2011).

\section{CLAUDIN-5}

Claudin adalah komponen struktur utama persimpangan ketat. Ekspresi claudin-1, -3, -5, dan -12 juga telah dikenal pasti pada otak manusia. Claudin-5 banyak diekspresi pada sel endotelium otak kerana kekurangannya mengakibatkan peningkatan ketelapan rintangan darah otak dalam model tikus kajian (Yamazaki \& Kanekiyo 2017).

Ekspresi protein persimpangan ketat dan molekul penyesuai yang menghubungkan persimpangan ketat ke protein sitoskeleton aktin terjejas dalam penyakit sistem saraf pusat akut dan kronik. Hal ini menunjukkan bahawa pengubahsuaian komponen persimpangan ketat dapat menyumbang kepada patogenesis sesuatu penyakit (Zenaro et al. 2017).

Menurut kajian lepas, ekspresi okludin, claudin-5 dan zona okludin-1 (ZO-1) telah menurun dalam pesakit Alzheimer dan hal ini menunjukkan bahawa modulasi ekspresi protein persimpangan ketat dapat meningkatkan ketelapan vaskular dalam otak. Okludin, claudin-5 dan ZO-1 juga dianggap sebagai indikator atau penanda biologi yang sensitif terhadap perubahan struktur dalam rintangan darah otak semasa patogenesis penyakit (Zenaro et al. 2017).

\section{KESIMPULAN}

Pengawalaturan seimbang proses autofagi pada sel endotelium terutamanya pada persekitaran otak adalah sangat penting bagi membolehkan sel-sel otak dan yang berkaitan pada sistem saraf pusat ini menjalankan fungsi fisiologi yang sempurna. Kegagalan fungsi autofagi boleh menyebabkan perkembangan kepada penyakit berkaitan neurodegeneratif. Justeru, kajian bagaimana proses ini berlaku amat penting bagi membolehkan langkah pencegahan teraputik dilakukan.

\section{PENGHARGAAN}

Penulisan ini dibiayai oleh geran GGPM-2017-044.

\section{RUJUKAN}

Bhutia, S.K., Mukhopadhyay, S., Sinha, N., Das, D.N., Panda, P.K., Patra, S.K., Maiti, T.K., Mandal, M., Dent, P., Wang, X.Y., Das, S.K., Sarkar, D. \& Fisher, P.B. 2013. Autophagy: Cancer's friend or foe? In Advances in Cancer Research. Massachusetts: Academic Press. pp. 61-95.

Bonaldo, P. \& Sandri, M. 2013. Cellular and molecular mechanisms of muscle atrophy. Disease Models \& Mechanisms 6(1): 25-39.

Choi, A.M., Ryter, S.W. \& Levine, B. 2013. Autophagy in human health and disease. New England Journal of Medicine 368(7): 651-662.

Chun, Y. \& Kim, J. 2018. Autophagy: An essential degradation program for cellular homeostasis and life. Cells 7(12): 278.

Cuomo, F., Altucci, L. \& Cobellis, G. 2019. Autophagy function and dysfunction: Potential drugs as anti-cancer therapy. Cancers 11(10): 1465.

Dai, S., Wang, B., Li, W., Wang, L., Song, X., Guo, C., Li, Y., Liu, F., Zhu, F., Wang, Q., Wang, X., Shi, Y., Wang, J., Zhao, W. \& Zhang, L. 2016. Systemic application of 3-methyladenine markedly inhibited atherosclerotic lesion in ApoE-/- mice by modulating autophagy, foam cell formation and immunenegative molecules. Cell Death \& Disease 7(12): 2498.

Di Marco, L.Y., Venneri, A., Farkas, E., Evans, P.C., Marzo, A. \& Frangi, A.F. 2015. Vascular dysfunction in the pathogenesis of Alzheimer's disease - A review of endothelium-mediated mechanisms and ensuing vicious circles. Neurobiology of Disease 82: 593-606.

Eskelinen, E.L. 2006. Roles of lamp-1 and lamp-2 in lysosome biogenesis and autophagy. Molecular Aspects of Medicine 27(5-6): 495-502.

Eskelinen, E.L. \& Saftig, P. 2009. Autophagy: A lysosomal degradation pathway with a central role in health and disease. Biochimica et Biophysica Acta (BBA)-Molecular Cell Research 1793(4): 664-673.

Fang, C., Gu, L., Smerin, D., Mao, S. \& Xiong, X. 2017. The interrelation between reactive oxygen species and autophagy in neurological disorders. Oxidative Medicine and Cellular Longevity 2017: 8495160. 
Fang, L., Li, X., Zhong, Y., Yu, J., Yu, L., Dai, H. \& Yan, M. 2015. Autophagy protects human brain microvascular endothelial cells against methylglyoxalinduced injuries, reproducible in a cerebral ischemic model in diabetic rats. Journal of Neurochemistry 135(2): 431-440.

Gimbrone Jr., M.A. \& García-Cardeña, G. 2016. Endothelial cell dysfunction and the pathobiology of atherosclerosis. Circulation Research 118(4): 620-636.

Glick, D., Barth, S. \& Macleod, K.F. 2010. Autophagy: Cellular and molecular mechanisms. The Journal of Pathology 221(1): 3-12.

Grammas, P. 2011. Neurovascular dysfunction, inflammation and endothelial activation: Implications for the pathogenesis of Alzheimer's disease. Journal of Neuroinflammation 8(1): $1-12$.

Grammas, P., Martinez, J. \& Miller, B. 2011. Cerebral microvascular endothelium and the pathogenesis of neurodegenerative diseases. Expert Reviews in Molecular Medicine 13: e19.

Green, D.R. \& Levine, B. 2014. To be or not to be? How selective autophagy and cell death govern cell fate. Cell 157(1): 65-75.

Hawkins, B.T. \& Davis, T.P. 2005. The blood-brain barrier/ neurovascular unit in health and disease. Pharmacological reviews 57(2): 173-185.

Huang, C.W., Tsai, M.H., Chen, N.C., Chen, W.H., Lu, Y.T., Lui, C.C., Chang, Y.T., Chang, W.N., Chang, A.Y. \& Chang, C.C. 2015. Clinical significance of circulating vascular cell adhesion molecule-1 to white matter disintegrity in Alzheimer's dementia. Thrombosis and Haemostasis 114(6): 1230-1240.

Jiang, F. 2016. Autophagy in vascular endothelial cells. Clinical and Experimental Pharmacology and Physiology 43(11): 1021-1028.

Kaushik, S. \& Cuervo, A.M. 2012. Chaperone-mediated autophagy: A unique way to enter the lysosome world. Trends in Cell Biology 22(8): 407-417.

Komarova, Y.A., Kruse, K., Mehta, D. \& Malik, A.B. 2017. Protein interactions at endothelial junctions and signaling mechanisms regulating endothelial permeability. Circulation Research 120(1): 179-206.

Liu, W.J., Ye, L., Huang, W.F., Guo, L.J., Xu, Z.G., Wu, H.L., Yang, C. \& Liu, H.F. 2016. P62 links the autophagy pathway and the ubiqutin-proteasome system upon ubiquitinated protein degradation. Cellular \& Molecular Biology Letters 21(1): 29.

Magaki, S., Tang, Z., Tung, S., Williams, C.K., Lo, D., Yong, W.H., Khanlou, N. \& Vinters, H.V. 2018. The effects of cerebral amyloid angiopathy on integrity of the blood-brain barrier. Neurobiology of Aging 70: 70-77.

Mauthe, M., Orhon, I., Rocchi, C., Zhou, X., Luhr, M., Hijlkema, K.J., Coppes, R.P., Engedal, N., Mari, M. \& Reggiori, F. 2018. Chloroquine inhibits autophagic flux by decreasing autophagosome-lysosome fusion. Autophagy 14(8): 14351455 .

Mizushima, N., Yoshimori, T. \& Levine, B. 2010. Methods in mammalian autophagy research. Cell 140(3): 313-326.
Mizushima, N., Levine, B., Cuervo, A.M. \& Klionsky, D.J. 2008. Autophagy fights disease through cellular self-digestion. Nature 451(7182): 1069-1075.

Nawawi, H., Osman, N.S., Annuar, R., Khalid, B.A.K. \& Yusoff, K. 2003. Soluble intercellular adhesion molecule-1 and interleukin-6 levels reflect endothelial dysfunction in patients with primary hypercholesterolaemia treated with atorvastatin. Atherosclerosis 169(2): 283-291.

Nixon, R.A. 2013. The role of autophagy in neurodegenerative disease. Nature Medicine 19(8): 983-997.

Noratiqah, S.B.S., Mohamed, I.N., Zulfarina, M.S. \& Qodriyah, H.M.S. 2018. Natural polyphenols in the treatment of Alzheimer's disease. Current Drug Targets 19(8): 927-937.

Nussenzweig, S.C., Verma, S. \& Finkel, T. 2015. The role of autophagy in vascular biology. Circulation Research 116(3): 480-488.

Ostrowski, P.P., Fairn, G.D., Grinstein, S. \& Johnson, D.E. 2016. Cresyl violet: A superior fluorescent lysosomal marker. Traffic 17(12): 1313-1321.

Park, K.H. \& Park, W.J. 2015. Endothelial dysfunction: Clinical implications in cardiovascular disease and therapeutic approaches. Journal of Korean Medical Science 30(9): 1213-1225.

Pugsley, H.R. 2017. Assessing autophagic flux by measuring LC3, p62, and LAMP1 co-localization using multispectral imaging flow cytometry. Journal of Visualized Experiments 125: 55637.

Rajendran, P., Rengarajan, T., Thangavel, J., Nishigaki, Y., Sakthisekaran, D., Sethi, G. \& Nishigaki, I. 2013. The vascular endothelium and human diseases. International Journal of Biological Sciences 9(10): 1057-1069.

Sambri, I. \& Fraldi, A. 2015. Lysosomal dysfunction in neurodegenerative disease. Advances in Clinical Neuroscience \& Rehabilitation 15(1): 13-15.

Settembre, C., Fraldi, A., Medina, D.L. \& Ballabio, A. 2013. Signals from the lysosome: A control centre for cellular clearance and energy metabolism. Nature Reviews Molecular Cell Biology 14(5): 283-296.

Shen, H.M. \& Mizushima, N. 2014. At the end of the autophagic road: An emerging understanding of lysosomal functions in autophagy. Trends in Biochemical Sciences 39(2): 61-71.

Si, L.Y., Kamisah, Y., Ramalingam, A., Lim, Y.C., Budin, S.B. \& Zainalabidin, S. 2017. Roselle supplementation prevents nicotine-induced vascular endothelial dysfunction and remodelling in rats. Applied Physiology, Nutrition, and Metabolism 42(7): 765-772.

Sun, H.J., Wu, Z.Y., Nie, X.W. \& Bian, J.S. 2020. Role of endothelial dysfunction in cardiovascular diseases: The link between inflammation and hydrogen sulfide. Frontiers in Pharmacology 10: 1568.

Tekirdag, K. \& Cuervo, A.M. 2018. Chaperone-mediated autophagy and endosomal microautophagy: Joint by a chaperone. The Journal of Biological Chemistry 293(15): 5414-5424. 
Ugusman, A., Zakaria, Z., Chua, K.H., Nordin, N.A.M.M. \& Mahdy, Z.A. 2014. Role of rutin on nitric oxide synthesis in human umbilical vein endothelial cells. The Scientific World Journal 2014: 169370.

Ugusman, A., Zakaria, Z., Hui, C.K. \& Nordin, N.A.M.M. 2010. Piper sarmentosum increases nitric oxide production in oxidative stress: A study on human umbilical vein endothelial cells. Clinics 65(7): 709-714.

Yamazaki, Y. \& Kanekiyo, T. 2017. Blood-brain barrier dysfunction and the pathogenesis of Alzheimer's disease. International Journal of Molecular Sciences 18(9): 1965.

Yang, Z. \& Klionsky, D.J. 2010. Mammalian autophagy: Core molecular machinery and signaling regulation. Current Opinion in Cell Biology 22(2): 124-131.

Yoshii, S.R. \& Mizushima, N. 2017. Monitoring and measuring autophagy. International Journal of Molecular Sciences 18(9): 1865.
Zenaro, E., Piacentino, G. \& Constantin, G. 2017. The bloodbrain barrier in Alzheimer's disease. Neurobiology of Disease 107: 41-56.

Program Sains Bioperubatan

Pusat Kajian Toksikologi dan Risiko Kesihatan (CORE)

Fakulti Sains Kesihatan

Universiti Kebangsaan Malaysia

50300 Kuala Lumpur, Wilayah Persekutuan

Malaysia

*Pengarang untuk surat-menyurat; email: nurulfarhana@ukm. edu.my

Diserahkan: 26 April 2020

Diterima: 30 September 2020 